\title{
The Factors Influencing Mobile Banking Usage among University Staff
}

\author{
YATY SULAIMAN $_{1,2}^{1}$, NORFADHILLAH JAUHARI ${ }^{2}$ \\ ${ }_{1,2}$ School of Business Management, \\ College of Business, \\ Universiti Utara Malaysia, \\ Kedah, \\ MALAYSIA
}

\begin{abstract}
This study examine customer's influencing factors to use mobile banking. To achieve the objectives of this study, four variables has been discussed which are perceived usefulness, perceived ease to use, perceived enjoyment and perceived credibility. 400 questionnaires were distributed to

Universiti Utara Malaysia (UUM) staff's. The data of this study was analyzed using computer peripherals Social Science Statistics Package (SPSS) version 23. Study found that all the variables are significant influencing customer's usage of mobile banking except for perceived enjoyment.

Key-Words: - Perceived usefulness, perceived ease to use, perceived enjoyment, perceived credibility and mobile banking
\end{abstract}

Received: August 9, 2020. Revised: November 21, 2020. Accepted: December 24, 2020. Published: January 12, 2021

\section{Introduction}

The percentage of mobile phones users are very high and almost everyone is using it in today's world. Mobile phones are being inevitable as it has been incorporated into all human activities. The cause of this growth is driven by more affordable smartphones and mobile data plans [1]. For example, from entertainment to financial transactions or even in doing business [2], the increased usage of smart phones influences adoption of mobile banking by most customers in the next few years. Besides, prompt growth of information technology has also impact banking industry as a whole. One of its effects is the introduction to mobile banking [3]. Retail banking customers those days have to visit their nearest banks to access any financial services [2], but now it becomes lesser. Mobile technologies has become trendy among upcoming generations who are the future users of mobile banking which being a worthwhile service to generate revenue [4].

Today's Banks are focussed to adopt new technologies due to the increased competition in banking sector [5]. Electronic banking aims to avoid long queues at Automatic Cashier Machine (ATM), [6]. Technology is becoming an increasingly important element in the modest panorama in financial services industry. Upgraded broadband and wireless technology networks have created opportunities for more widespread and convenient use of mobile commerce services, [7]. Additionally, researchers [8], found that today's banking is undergoing a radical change. They can see new signs of development every day such as new products, new players and even new channels. Most of these transformations are steering in the banking industrial sector. According to the budget made by global ratings, as many as 7 billion mobile subscriptions are used by mobile phone users and with that estimation, advertisers and operators are beginning to realize the opportunity to connect with potential users via mobile phones [8].

Despite that even though there are numerous benefits for customers, but the actual usage of mobile banking has not increased at a rate as initially anticipated [9]. Service providers are more interested in improving their understanding of consumer behaviour patterns to oversee challenges [8]. The use of internet has become an enormous distribution channel and challenges businesses or companies to change from a traditional approach to electronic business. Most of the firms in Malaysia are challenged to make changes with technology advancement. 
Most of the banks has enhanced electronic banking system by introducing mobile banking. This system is mostly unaware by customers even though efforts taken to develop a better and easier mobile banking system. The number of online banking customers in Malaysia is still low compared to total broadband subscriptions at 3.25 million with a mobile penetration rate of 10.9 per cent of total population and 7.6 per cent from mobile phone users [9]. This indicates that those who use online banking services are still a minority [10]. The number of transactions through mobile banking per capita is relatively low compared to other payment methods [11]. Meaning that, apart from the use of ICT for financial services and especially in mobile banking services, there are still other obstacles that need to be faced with technological efficiency. Statistics shown in tables 1.1 and 1.2 are about mobile banking acceptance among consumers in Malaysia.

\section{Mobile Banking Customers (Final Period)}

Table 1.1: Mobile Banking Penetration Rate for 2015

\begin{tabular}{|c|c|c|c|}
\hline \multirow{2}{*}{$\begin{array}{l}\text { YEAR } \\
(0000)\end{array}$} & \multirow{2}{*}{$\begin{array}{l}\text { NUMBER OF MOBILE } \\
\text { BANKING CUSTOMERS }\end{array}$} & \multicolumn{2}{|c|}{ REDEMPTION RATE (\%) } \\
\hline & & POPULATION & CUSTOMERS \\
\hline 2005 & 127.6 & 0.5 & 0.7 \\
\hline 2006 & 246.7 & 0.9 & 1.3 \\
\hline 2007 & 367.6 & 1.4 & 1.6 \\
\hline 2008 & 574.6 & 2.1 & 2.1 \\
\hline 2009 & 675.0 & 2.4 & 2.2 \\
\hline 2010 & 898.5 & 3.1 & 2.6 \\
\hline 2011 & $1,560.3$ & 5.3 & 4.3 \\
\hline 2012 & $2,446.2$ & 8.2 & 5.9 \\
\hline 2013 & $4,378.8$ & 14.6 & 10.2 \\
\hline 2015 & $5,639.2$ & 18.6 & 12.9 \\
\hline SEPT-15 & $7,001.4$ & 23.0 & 15.2 \\
\hline
\end{tabular}

Table 1.2: Number of Cellular Phone Subscriptions and Penetration Rates for 2015

\begin{tabular}{|l|l|l|l|l|l|}
\hline YEAR & QUATER & $\begin{array}{l}\text { POSTPAID } \\
\left({ }^{\prime}(000)\right.\end{array}$ & $\begin{array}{l}\text { PREPAY } \\
\left({ }^{(} 000\right)\end{array}$ & $\begin{array}{l}\text { TOTAL } \\
\left({ }^{\circ} 000\right)\end{array}$ & $\begin{array}{l}\text { REDUCATION RATE PER } \\
1000 \text { POPULATION }\end{array}$ \\
\hline 2014 & 1 & 7,860 & 35,388 & 43,248 & 144.2 \\
\hline & 2 & 7,986 & 35,892 & 43,878 & 145.8 \\
\hline & 3 & 8,028 & 35,761 & 43,789 & 145.5 \\
\hline & 4 & $\underline{8,149}$ & $\underline{36,780}$ & $\underline{44,929}$ & $\underline{148.3}$ \\
\hline 2015 & 1 & 8,258 & 36,160 & 44,418 & 146.2 \\
\hline
\end{tabular}

Furthermore, several previous studies is showing that low occupancy of mobile banking services which can further support the problem statement of this study. Consumers' attitudes towards online and mobile banking in China shows that fear of security risks being the main reason for users not using this service [12]. Apart from that, they also found that lack of technological skills on computers associated with lack of internet use and mobile banking.
Study in Nigeria revealed that the main constraints to use mobile banking is because of weak security network, ineffective telecommunication infrastructure especially in rural areas and lack of internet knowledge and poor computer skills [13]. Furthermore, they found that mobile phones are mainly focused on the basic function of making and receiving calls and sometimes only to send text messages. Although there is evidence that electronic revolution has begun, there is still a need to understand the acceptance of mobile banking users and to identify factors that can affect the behaviour of users' intention to use mobile banking [14].

\section{LITERATURE REVIEW}

\subsection{Technology Acceptance Model Theory (TAM)}

Technology acceptance model (TAM) has generally used to study factors influencing use of information systems. It was originally developed from causal action theory (TRA) introduced by [15]. Main objective of this model to provide an explanation on determination of computer technology acceptance and behaviour of users across various computing technologies as end users [16]. In fact, this model shows that user acceptance of new information system is determined by two main factors namely perceived usefulness and perceived ease to uses. This perception will shape the attitude and this attitude will develop into intention and in turn drive towards the actual use of the system.

However, there are some variables being neglected in this model that affects user acceptance such as trust-based constructs and resource-based constructs. In addition, several constructs have been added to the original technology adoption model where it will facilitate understanding of the use of information systems [17]. Technology acceptance model is further expanded to include the development of technological acceptance theory which does not address technological factors and the use of specific contexts that can also change an individual's behaviour in decision making [17].

\subsection{Mobile Banking in Malaysia}

Mobile phones is a tool used daily to create opportunities in improving banking services to attain customers through mobile banking 
services. This service is considered as the newest and most potential application in mobile commerce which has a great mobility and flexibility to make financial transactions through mobile telecommunications devices [18]. With technology advancement, Malaysia's economic can focus on various sectors [19]. Maybank Malaysia to come up with free banking application. After that, CIMB Bank Berhad has introduced CIMB Clicks and this application has become famous and most used banking application in Malaysia [20]. Lately, Bank Islam has also started to provide mobile banking services to their customers in October 2010. With this, account holders will be able to perform their banking transactions at anytime and anywhere without having to access the internet.

\subsection{Consumer Attitudes Toward Mobile Banking}

A few researchers has pointed out that attitudes is about the beliefs of engaging with behaviours and assessments. Theory of attitude notices that if a person has an encouraging attitude on a given product or service they will be more likely prefer to buy or use the product or services. Study about consumer attitudes and the use of electronic banking identify several preliminary factors determine consumer attitudes towards online and mobile banking such as demographics, motivation and behaviour and individual acceptance of new technologies [21]. Although consumer decisions are relatively easy to notice and quantify but their physiological processes are difficult to consider [22]. An individual using mobile phones for their banking activities responses towards mobile banking [23].

\subsection{Demographics and Personality Traits of Users}

Many researchers found that consumer's behaviour needs to be studied through demographics, beliefs and attitudes [24]. Demographic factors is widely known to significantly influence consumer attitudes and behaviours in internet banking and mobile banking. Mobile banking or internet banking users are identified to be from the upper-middleclass members of high-ranking people and members of lower middle class [25]. Many researchers find that elder consumers are having difficulties with latest technologies and expected to be not interested towards innovation. Besides many older users of the fungus are negative towards change [26]. Age has least effect on attitudes and intentions towards the adoption of new technologies [27]. To deliver a profitable value product and services, organisations needs to develop competitively superior value of preferences that will not easily change the product or services [28].

\subsection{Factors Influencing Consumers on Mobile Banking}

\subsubsection{Perceived Usefulness}

Perceived Usefulness is known to be the first factor of technology acceptance model (TAM). Perceived usefulness is closely related to productivity of computers to improve job performance and work usability at workplace. Perceived usefulness as a person believes in using a system to improve their respective job performance [29]. It is also the key informants to determine behavioural goals by using computer systems [30]. Customers' attitudes and behaviours to adopt services will increase once they are aware of the importance of technology. Perceived usefulness is seen to directly impact attitudes towards mobile banking among 435 students at University of Turkey [31]. Perceived usefulness was an important factor to determine the intention to adopt this service among mobile banking consumers in Malaysia [32]. There are positive cause and effect between the benefits and intentions in online purchases [33].

$\mathrm{H} 1$ : Perceived usefulness have an influence on consumer attitudes in mobile banking.

\subsubsection{Perceived Ease to Use}

Perceived ease to use is the second element in technology acceptance model. It defines how a system interacts with users for a clearer instruction as well as easy to comprehend when they are using the system [34]. At the bottom of the pyramid in South Africa, perceived ease to use is seen to have a significant impact on the use of mobile banking [35]. Perceived ease to use encourage university students in South Africa to use mobile banking [36]. said perceived ease to use positively impact the development of early readiness for the use of internet banking [37]. There are positive cause and effect between perceived ease to use and intention to use [38]. Perceived ease to use is where a person believes 
a specific system will be free from effort to use [39]. Perceived ease to use has a significant intention in adopting mobile banking services [40]. Extensive study says that perceived ease to use positively impact intention of use and being a significant predictor in the use of technology.

H2: Perceived Ease to Use have an influence on consumer attitudes in mobile banking.

\subsubsection{Perceived Enjoyment}

Perceived enjoyment is where a computer based activities are fun with a distinctive style. Perceived enjoyment significantly associated with behavioural intentions of mobile banking SMS and being a strong determinant for female consumers compared to male consumers [41]. Perceived enjoyment is considered insignificant with the use of internet banking [42]. Apparently, perceived enjoyment does not affect acceptance of data processing systems [43]. Perceived enjoyment is a performance of activities without clear reinforcement apart from doing an activity [44]. The use of systems with perceived enjoyment has positively linked to each other.

H3: The perceived enjoyment has an influence on consumer attitudes in mobile banking.

\subsubsection{Perceived Credibility}

Perceived credibility consists of security and privacy where it has been identified in many previous studies, saying that it affects behavioural intentions of users who practice internet-based trading systems [45]. Customers typically distance themselves from service providers when they don't trust [46]. Perceived credibility refers to users who feel certain and pleasant as a result of using electronic application services [47]. Since mobile banking was introduced as a new banking tool, security and privacy issues have become important to understand the acceptance of mobile banking. It is a necessity to state security and privacy concern in the acceptance of bank customers in mobile banking. Security and privacy factors are crucial in perceived credibility [45]. Many banking studies have been conducted and it states that security and privacy are very important for mobile banking acceptance [21].

Perceived credibility is found to be related to consumer acceptance of internet and mobile banking [21]. It generally recognizes that perceived credibility has a significant role in a person's decision in adopting new technologies including mobile banking [48]. At the same time, perceived credibility widely able to predict and reflect the desire of consumers to accept and use electronic banking [49]. There are some implications for customers' voluntary acceptance of mobile banking. These include securing the completion of transactions and maintaining personal details. Since mobile banking is still new, perceived credibility having more opportunity to predict and explain the intentions and attitudes of consumers to use mobile banking system.

H4: The perceived credibility has an influence on consumer attitudes in mobile banking.

\section{Methodology}

\subsection{Research Design}

Research design consist of planning data collection, measurement and analysis constructed on research questions [50]. Researchers identified variables within the theoretical framework to come out the research design for this study. Researcher chooses descriptive study to collect data that describes about individual characteristics, events or situations.

\subsection{Sampling Design}

Surveys are useful and effective to find solutions to research questions from subsequent data collection and exploration [50]. This study uses random sampling because each component in the population has an equal chance of being selected as the subject in the sample. The purpose of an easy-to-use random sample is to decrease the potential of human tendencies on case selection to be included in the sample. At the end, a simple random sample will provide researcher a sample representing the population studied, assuming that the data are limited.

\subsection{Target Population}

The population of study are staff from Universiti Utara Malaysia (UUM). This population can be described as a whole cluster of people, events or important things that researchers want to study [50]. According to the data from Registrar's Department, there are five thousand employees (5000) working at Universiti Utara Malaysia. A sample size of 357 respondents is measured adequate to represent the entire UUM staff [51]. 
For an effective data, a total of 400 respondents were picked to conduct this study.

\subsection{Sample Size}

Sample size is the number of segments calculated [52]. The population of this study was staff working at UUM with a sample size was 400 respondents. Of these 400 respondents, a total of twenty-five (25) out of sixteen (16) departments were randomly selected to answer the questionnaire. These respondents were picked through a list of names obtained through Registrar's Department according to the odd number from the list of names. All selected respondents were given 30 minutes to do the questionnaire. While 400 questionnaires were distributed, only 380 managed to collect back and can be used while 15 were not returned, 3 were incomplete and 2 were rejected because respondents did not answer according to the required specifications.

Table 1: Sample Size According to Krejcie \& Morgan (1970) Schedule

\begin{tabular}{cc}
\hline Population Size (N) (N) & Sample Size (S) \\
\hline 4000 & 351 \\
4500 & 354 \\
5000 & 357 \\
6000 & 361 \\
$7000 \mid$ & 364 \\
\hline
\end{tabular}

\subsection{Questionnaire Design}

Questionnaire is an efficient data collection tool to be used in descriptive studies [50]. Questionnaire of this research was designed to examine consumer attitudes towards mobile banking. There are six sections in this questionnaire. First is part A, respondents were asked about their personal backgrounds such as gender, age, marital status, educational background, awareness of mobile banking, experience of using mobile banking, duration of using mobile banking and the type of financial transactions that are always used by respondents. Meanwhile, part B to part F, respondents were asked about questions related to dependent and independent variables which had been adapted from several previous researchers. Items of dependent and independent variables were adapted from previous literature studies using the Five Point Likert Scale ranging from values 1 to 5 .

\subsection{Data Collection Methods 3.6.1 Data Processing Methods}

Commonly, there are primary data and secondary data collections methods. This study uses primary data as a method of data collection. This research distributed questionnaire as the main method to collect data from respondents. Questionaire was in dual-language which is Malay and English.

The data of this research was analyzed with computer peripherals Social Science Statistics Package (SPSS) version 23. Reliability tests will be used to find out the value of Crobach Alpha.

\subsection{Research Framework}

Research framework is formed with a combination of new Technology Acceptance Models. This model is commonly used to study technology acceptance. As an example, actual behaviour is formed by two main factors namely perceived usefulness and perceptual perceptions which are related to attitudes related to intention and ultimately to behaviour [34]. TAM is based on Cognitive Action Theory (TRA) where it deals with conscious behaviour determinants [15].

Therefore, this study has further expanded by including perceived enjoyment and perceived credibility towards mobile banking. Perceived enjoyment was to identify if the system provides pleasure when using it. Previous study found that perceived enjoyment is seen to be positively correlated with frequency of internet use [53]. Apart from that, this study also develops perceived credibility as a new TAM factor to further explain consumer safety, privacy and financial risk concerns in consumer acceptance of electronic banking. Perceived credibility is the lifeblood of internet banking system and computer self-efficacy impacts perceived ease to use [32].

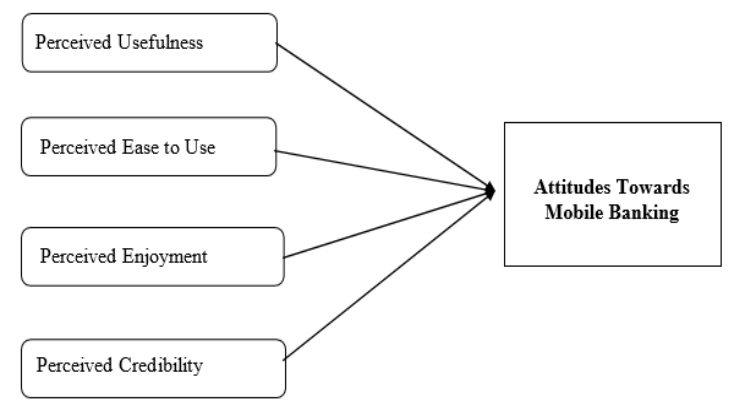


Figure 1 Research Framework on Attitudes towards Mobile Banking

\section{Findings}

\subsection{Regression Analysis}

Regression analysis were used to study the strength of the correlation between independent variables namely perceived usefulness, perceived ease to uses, Perceived Enjoyments and Perceived Credibility with dependent variables i.e. consumer attitudes on mobile banking. The strength of such relationships able to identify which type of relationship is more significant to attitudes towards mobile banking. The regression results are as shown in Table 1,2 and 3 below.

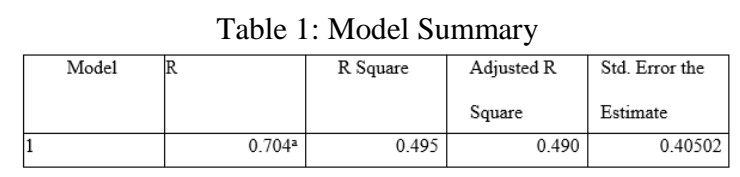

\begin{tabular}{|c|c|c|c|c|c|c|}
\hline & Model & $\begin{array}{l}\text { Sum of } \\
\text { Square }\end{array}$ & Df & $\begin{array}{l}\text { Mean } \\
\text { Square }\end{array}$ & $\mathrm{F}$ & Sig. \\
\hline 1 & $\begin{array}{l}\text { Regression } \\
\text { Residual } \\
\text { Total }\end{array}$ & $\begin{array}{r}60.397 \\
61.514 \\
121.911\end{array}$ & $\begin{array}{l}4 \\
375 \\
379\end{array}$ & $\begin{array}{r}15.009 \\
0.164\end{array}$ & 92.047 & $0.000^{\mathrm{a}}$ \\
\hline
\end{tabular}

Table 3: Regression Analysis of Perceived usefulness, Easy to Use Perceptions, Perceived Enjoyments and Perceived Credibilitys with User Attitudes

\begin{tabular}{|c|c|c|c|c|c|c|}
\hline \multirow{2}{*}{\multicolumn{2}{|c|}{ Model }} & \multicolumn{2}{|c|}{$\begin{array}{l}\text { Unstandardized } \\
\text { Coefficients }\end{array}$} & \multirow{2}{*}{ 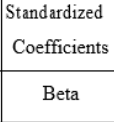 } & \multirow[b]{2}{*}{$\mathrm{t}$} & \multirow[b]{2}{*}{ Sig. } \\
\hline & & B & Std. Error & & & \\
\hline \multirow[t]{5}{*}{1} & (Constant) & .569 & 188 & & 3.027 & .003 \\
\hline & mean_PU & .501 & .055 & .473 & 9.071 & .000 \\
\hline & mean_PEOU & .181 & .063 & .164 & 2.880 & .004 \\
\hline & mean_PE & .049 & .051 & .050 & .970 & .333 \\
\hline & mean_PC & .109 & .042 & .123 & 2.589 & .010 \\
\hline
\end{tabular}

Nota: $\mathrm{R}^{2}=0.50 ; \mathrm{F}=92.05 ;$ Sig. $\mathrm{F}=0.00 ; * * \mathrm{p}<0.05$

Tables 1, 2 and 3 shows independent variables influence attitudes towards mobile banking. F- Statistical values $(\mathrm{F}=92.05, \mathrm{p}=$ $0.05)$ indicate that the connection between dependent and independent variables is important. R2 value indicates that independent variables i.e. perceived usefulness, ease of use, perceptions of fun and perceptions of credibility are seen to have a value of 50 per cent of the variation in attitudes towards mobile banking. This means that all variables are considered important with attitudes towards mobile banking.

Results shows that only 3 variables are having a significant and positive values, that is perceived usefulness, Perceived Ease to Use and Perceived Credibility. While perceived enjoyment is insignificant because it exceeds the predetermined value of $p=0.05$. Next, the highest beta value $(\beta)$ is perceived ease to use of 0.47 followed by easy-to-use notion $(\beta=0.16)$, the perceived credibility $(\beta=0.12)$, and the last is the pleasant notion $(\beta=0.05)$.

Therefore, 3 out of 4 hypotheses which are Perceived usefulness (H1), Easy to Use (H2) and Perceived Credibility (H4) have an influence on consumer attitudes on mobile banking and accepted hypotheses. Hypothesis for Perceived enjoyment (H3) is rejected because it has an insignificant influence that is Significant value exceeds 0.05 (Sig.0.33).

\subsection{Pearson Correlation Analysis}

Table 4 shows results from correlation analysis. Pearson correlation coefficient calculations were conducted to gain an understanding the relationship between all variables in this study. Values of correlation coefficient (r) given in the table shows the strength of variables. As shown in the correlation between variables indicates that all independent variables are significant with dependent variables. Correlation is positive and generally strong with correlation values ranging from 0.53 to 0.66. Attitudes towards mobile banking were positive with perceived usefulness $(r=0.66)$, ease of use $(r=0.57)$, perceptions of fun $(\mathrm{r}=0.54)$ and perceptions of credibility $(\mathrm{r}=$ $0.53)$.

Table 4: Pearson Correlation Analysis Value 


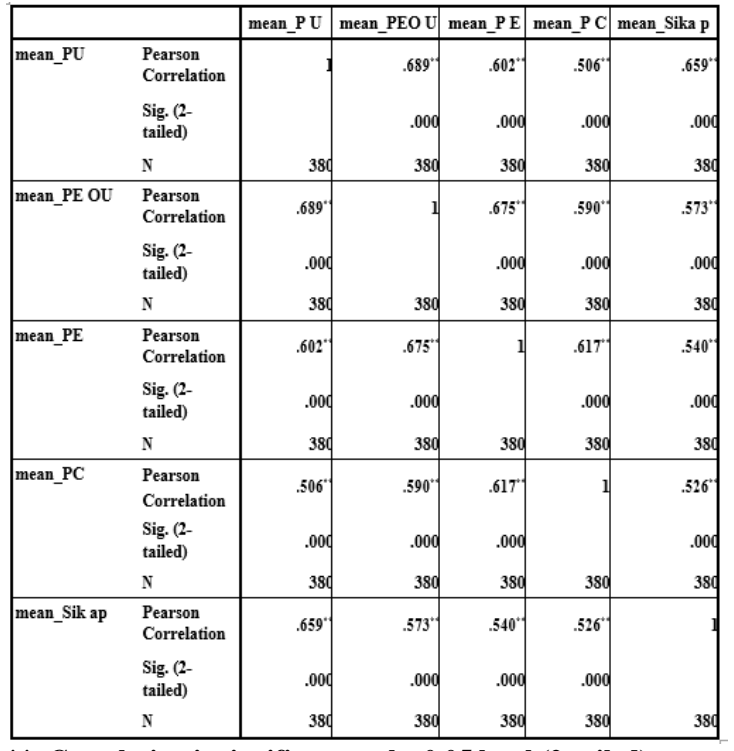

**. Correlation is significant at the 0.05 level (2-tailed).

\subsection{Reliability Test}

Results of reliability test are shown in the Table below.

Table 5: Reliability Tests

\begin{tabular}{|l|c|c|}
\hline \multicolumn{1}{|c|}{ VARIABLES } & $\begin{array}{c}\text { NUMBER OF } \\
\text { ITEMS }\end{array}$ & $\begin{array}{c}\text { CRONBACH'S ALPHA } \\
\text { VALUE }(\mathrm{n}=380)\end{array}$ \\
\hline Perceived Usefulness & 8 & 0.89 \\
\hline Easy to Use Feedback & 6 & 0.87 \\
\hline Perceived Enjoyments & 5 & 0.9 \\
\hline Perceived Credibility & 5 & 0.87 \\
\hline $\begin{array}{l}\text { Consumer Attitudes Towards Mobile } \\
\text { Banking }\end{array}$ & 8 & 0.85 \\
\hline
\end{tabular}

These results reveal that the reliability coefficients on independent variables and the dependent variables are between 0.85 to 0.90 . Therefore, the measurement of the independent and dependent variables in this study is considered acceptable because it has reached an alpha value of 0.7 and above [50].

\subsection{Summary of Hypothesis Test Results}

A summary of the hypothesis test results is described in Table 6 below:
Table 6: Summary of Hypothesis Test Results

\begin{tabular}{|l|l|c|}
\hline \multicolumn{2}{|l|}{ HYPOTHESIS DESCRIPTION } & RESULTS \\
\hline H1 & $\begin{array}{l}\text { Perceived usefulness have an upward significant } \\
\text { relationship with the attitude of mobile banking } \\
\text { users }\end{array}$ & Accepted \\
\hline H2 & $\begin{array}{l}\text { Perceived Ease to Use have a significant } \\
\text { relationship with the attitude of mobile banking } \\
\text { users }\end{array}$ & Accepted \\
\hline H3 & $\begin{array}{l}\text { Perceived Enjoyments have a significant } \\
\text { relationship with the attitude of mobile banking } \\
\text { users }\end{array}$ & Rejected \\
\hline H4 & $\begin{array}{l}\text { The perceived credibility have a significant } \\
\text { relationship with the attitude of mobile banking } \\
\text { users }\end{array}$ & Accepted \\
\hline
\end{tabular}

\section{Conclusion}

Results showed that the level of consumer awareness of mobile banking is high at $97 \%$, where else in terms of its use there is a slight difference of $90 \%$. This indicates that respondents are aware and has the knowledge of this service, yet they are less interested in using it. Female consumers have actually begun to adopt mobile banking. Found that $55 \%$ are female consumers while only $45 \%$ are male consumers. Users are basically from young age and having a high educational background. According to the results of this test, $55.3 \%$ are aged 21-30 and most of them have a bachelor's degree education. In conclusion, researchers found that mobile banking services are already being accepted by consumers especially by young consumers with a higher educational background. This is because they are interested to explore new things especially in technology related as well as efficient in the use of mobile phones. They are aware of this service and with enough information and trust they are feeling safe to use for their financial transactions.

Hypothesis 1: Perceived usefulness have an influence on consumer attitudes in mobile banking.

Hypothesis 1 is accepted as the findings of the study shows that perceived usefulness has a strong relationship and influence consumer attitudes towards mobile banking. Respondents are generally familiar with mobile phones such as the use of the internet or SMS. In addition, respondents also believe that the way they conduct banking transactions can be improved by using mobile banking as it is easy to use. 
Hypothesis 2: Perceived Ease to Use have an influence on consumer attitudes in mobile banking.

This hypothesis is accepted because the study shows that there is a strong influence and positive relationship between perceive ease of use with attitude of consumers towards mobile banking. The notion of ease of use is found to be a good predictor in explaining the intention to use mobile banking. Moreover, perceive usefulness, perceived ease of use, are important variables to the original theory of technological acceptance (TAM) (Davis, 1989) in which these two variables are adopted in information systems.

Hypothesis 3: Hypothesis 3: H3: The perceived enjoyment has an influence on consumer attitudes in mobile banking.

Perceived enjoyment was found to have a relationship but not influencing consumer attitudes towards mobile banking. So this hypothesis is rejected. Perceived enjoyment is seen to be positively correlated with frequency of internet use. In fact, he also clearly believes that the use of mobile banking offers is fun.

Hypothesis 4: H4: The perceived credibility has an influence on consumer attitudes in mobile banking.

These hypothesis suggests that perceive credibility has a strong influence and significant relationship with attitude of consumers in mobile banking and the result of this proposal is accepted. As expected, perceive credibility is an important factor in mobile banking as it relates to an individual's satisfaction. Researchers also believe that many respondents can adopt mobile banking facilities if a bank is more concerned with privacy issues and can protect the personal data of their customers.

Mobile banking in Malaysia is increasing among the Malaysian population as a developing country. There is good potential for bankers in this country to introduce more mobile banking facilities to consumers. However, in order to be more effective and user-friendly, some properties in the mobile banking system need to be emphasized such as easy to use or user-friendly, useful, attractive to use and reliable.

Banks needs to providing adequate information to consumers to build their confidence in mobile banking. User manual with information pertaining to mobile banking can be provided to them. In addition, they should also provide a special offering advice or assistance to bank customers regarding the use of mobile banking. Apart from that, banks must emphasize the importance of personal identification number (PIN). And ensure that security devices are correct, functional and enforced in mobile banking system.

\section{Acknowledgement}

Yaty Sulaiman is Associate Professor of Marketing, School of Business Management, College of Business, Universiti Utara Malaysia 06010 Sintok, Kedah, Malaysia. The author would like to thank The Ministry of Higher Education (MOHE) for granting this research under the Fundamental Research Grant Scheme (FRGS) and Research Innovation Management Centre (RIMC) Universiti Utara Malaysia. This article is under FRGS grant research.

\section{References}

[1] Digital in 2018. (n.d.). Retrieved from https://www.slideshare.net/wearesocia 1/digital-in-2018-globaloverview$\underline{86860338}$

[2] Monitise. (2012). Emerging Trends in Mobile Banking. Retrieved from Future Foundation: http://www.monitise.com/upload/asset s/docs/money-on-the-move/chapter 4

[3] Baba, R.; Muhammad, M.Z. (2012). An analysis of mobile banking acceptance by Malaysian customer. Sunway Academic Journal, 4, 1-12.

[4] Munongo,S \& Chitungo,S.K. (2013). Extending the Technology Adoption Model to Mobile Banking Adoption in Rural Zimbawbe. Journal of Business Administration and Education, 3(1): 51-79.

[5] Alalwan, A. A., Dwivedi, Y. K., \& Rana, N. P. (2017). Factors influencing adoption of mobile banking by Jordanian bank customers: Extending UTAUT2 with trust. International Journal of Information Management, 37(3), $\quad 99$ 110.https://doi.org/10.1016/j.ijinfomgt .2017.01.002

[6] Laukkanen, T. (2006). "Customer perceived value of e-financial services: a means-end approach," International 
Journal of Electronic Finance, 1(1), 517.

[7] AlShaali, S. and U. Varshney (2005), iOn the usability of mobile commerceî, International Journal of Mobile Communications, Vol. 3(1), pp. 29-37.

[8] Hamzar, S.K.; Younes, E.A.S. \& Aymen, S.K. (2011). "Factors Affecting Jordanian Consumer's Adoption of Mobile Banking Services. International Journal o Business and Social Science. 2(20), 96-105.

[9] The Star. 2013. Deputy Finance Minister: $14.6 \mathrm{~m}$ Internet banking subscribers in Malaysia. October 2. Available online: https://www.thestar.com.my/Business/ Business-News/2013/10/02/DeputyFinance-Minister-Internet-bankingsubscribers-in Malaysia/?style $=$ biz (accessed on 1 October 2020).

[10] Financial Stability Board (2013): FSB Publishes Policy Recommendations to Strengthen Oversight and Regulation of Shadow Banking, www.financialstabilityboard.org/press /pr_130829a.pdf, 29 August

[11] Malaysian Communications and Multimedia Commission. Communications \& Multimedia Pocket Book of Statistics; 2014. Available at http://www.skmm.gov.my/skmmgovm y/media/General/pdf/Q3-BI-PocketBook-of-Statistics.pdf. Retrieved from January 31, 2015.

[12] Laforet, S., \& Li, X. (2005). Consumers' attitudes towards online and mobile banking in China. International journal of bank marketing, 23(5), 362-380.

[13] Agwu, E (2012). A Qualitative Study of the Problems and Prospects of Online Banking in Nigeria. Journal of Internet Banking and Commerce 17: 119.

14] Ndubisi. N., Jantan, M. \& Richardson. S. (2001). Is the Technology Acceptance Model Valid for Enterpreneurs? Model Testing and Examining Usage Determinants. Asian Academy of Management Journal, 6 (2): 31-54.

[15] Ajzen, I., \& Fishbein, M. (1980). Understanding attitudes and predicting social behavior. Englewood Cliffs, NJ:
Prentice-Hall

[16] Chau, P.Y.K. (2001) "Influence of Computer Attitude and Self-efficacy on IT Usage Behavior" Journal of End User Computing 13(1), pp. 26-33.

[17] Luarn, P. \& Lin, H.H. (2005). “Toward an understanding of the behavioral intention to use mobile banking," Computer in Human Behavior, 21(5), 873-91.

[18] Lewis, 2015. Financial Inclusion, Financial Education and Financial Regulation in the United Kingdom. ADB Working Paper Series 544; Tokyo: Asian Development Bank Institute.

[19] Sulaiman, Y., Abu Bakar, N. Z. A., Shahril Ismail, N. Y., Nik Mat, N. K., Musa, R. (2017). The Function of Marketing Mix and Consumer Rreferences on Healthy Food Consumption among UUM Students. International Journal of Economic Research, 14 (19, 0972-9380.

[20] Krishnan, D., Khin, A. A., Kevin, L. L. T. (2015). Attitude towards Using Mobile Banking in Malaysia: A Conceptual Framework. British Journal of Economics, Management \& Trade. 7 (1), 2278-098X

[21] Howcroft, B.; Hamilton, R. \& Hewer, P. (2002). Consumer attitude and the usage and adoption of home-based banking in the United Kingdom. International Journal of Bank Marketing, 20(3), 111-121. Islamic Banking Act (IBA) 1983. Industrial Management and Data Systems, 110(3), 309-324

[22] Sulaiman, Y., Masri, M. (2017). The impact of marketing mix on consumer preference towards supplement product. Journal of Advanced Research in Social and Behavioural Sciences. 7 (1), 33-41.

[23] Venkatesh, V. (2000). Determinants of Perceived Ease of Use: Integrating Control, Intrinsic Motivation, and Emotion into the Technology Acceptance Model. Information Systems Research, 11 (4): 342-365

[24] Assael, H. (2010). "Consumer Behavior and Marketing Action, 3rd Ed. PWS-Kent Publishing Company, Boston, MA. 
[25] Jayawardhena, C. \& Foley, P. (2011). "Changes in the banking sectors: The case of Internet Banking in the UK," Internet Research: Electronic Networking Applications and Policy, 10(1), 19-30.

[26] Trocchia, P. J., \& Janda, S. (2011). A Phenomenological Investigation of Internet Usage among Older Individuals. Journal of Consumer Marketing, 17(7), $605-16$.

[27] Taylor S., Todd P. A. (1995). Understanding information technology usage: a test of competing models. Inf. Syst. Res. 6 144-176. 10.1287/isre.6.2.144

[28] Sulaiman, Y., Jamil, N. A. M., Othman, A. R., Musa, R. (2020). The Influence of Green marketing, Syariah Compliance, Customer's Environmental Awareness and Customer's Satisfaction towards Muslim Consumer Purchasing Behaviour in Kedah. DOI: 10.37394/23207.2020.17.21

[29] Davis, F.D. (1989). "Perceived usefulness, perceived ease of use and user acceptance of Information technology," MIS Quarterly, 13(3), 318-39. Educational and Psychological Measurement, 30, 607-610.

[30] Davis, F. D. \& Venkatesh, V. (1996). A Critical Assessment of Potential Measurement Biases in the Technology Acceptance Model: Three Experiments. International Journal of HumanComputer Studies, 45: 19-45.

[31] Akturan, U. \& Tezcan, N. (2012). "Mobile banking adoption of the youth market: Perceptions and intentions," Marketing Itelligence and Planning. 30(4).

[32] Amin, H.; Hamid,M.R.A.; Lada, S. \& Anis, Z (2008). "The Adoption of Mobile Banking In Malaysia: The Case of Bank Islam Malaysia Berhad (BIMB)," International Journal of Business and Society, (2), 43-53.

[33] Cheong, J.H. \& Park, M.C. (2005). Mobile internet acceptance in Korea. Internet Research, 15(2), 125-140.

[34] Davis, F.D. (1989). "Perceived usefulness, perceived ease of use and user acceptance of Information technology," MIS Quarterly, 13(3),
318-39. Educational and Psychological Measurement, 30, 607-610.

[35] Masinge, K. (2010). "Factors influencing the adoption of mobile banking services at the Bottom of the Pyramid in South Africa. Master's Thesis, Gordon Institute of Business Science, Sandton, South Africa

[36] Govender, I. \& Sihlali, W.A. (2014). "A study of mobile banking adoption among university students using an extended TAM," Mediterranean Journal of Social Sciences, 5(7), 451

[37] T. Ramayah, Muhamad Jantan, Mohd Nasser Mohd Noor, Koay Pei Ling (2003) Universiti Sains Malaysia. Receptiveness Of Internet Banking By Malaysian Consumers: The Case Of Penang.

[38] Luarn, P. \& Lin, H.H. (2005). "Toward an understanding of the behavioral intention to use mobile banking," Computer in Human Behavior, 21(5), 873-91

[39] Li, H., Liu, Y. 2014. Understanding post-adoption behaviors of e-service users in the context of online travel services. Information \& Management, 51(8), 1043-1052

[40] Cheah, C.M.; Teo,A.C.; Sim,J.J.; Oon, K.H.\& Tan, B.I. (2011). "Factors Affecting Malaysian Mobile Banking Adoption: An Empirical Analysis," International Journal of Network and Mobile Technologies. 2(3).

[41] Nysveen, H.; Pedersen, P.E. \& Thorbjornsen, H. (2005). Explaining intention to use mobile chat services: Moderating effects of gender. Journal of Consumer Marketing. 33(5), 247256.

[42] Pikkarainen, T.; Pikkarainen. K.; Karjaluoto, H. \& Pahnila, S. (2004). Consumer acceptance of online banking: An extension of the technology acceptance model. Internet Research, 14(3), 224-235.

[43] Igbaria, M., Guimaraes, T. \& Davis, G. B. (1995). Testing the Determinants of Microcomputer Usage Via a Structural Equation Model. Journal of Management Information Systems, 11 (4): 87-114.

[44] Igbaria, M., Parasuraman, S. \& Baroudi, J. J. (1996). A Motivational Model of 
Microcomputer Usage. Journal of Management Information Systems, 13 (1): 127-14

[45] Wang, Y.S.; Wang, Y.M.; Lin,H.H. \& Tang, T.I (2003). Determinants of user acceptance of internet banking: An empirical study. International Journal of Service Industry Management, 14(5), 501-519

[46] Reichheld, F.F. and Schefter, P., (2000), "E-Loyalty", Harvard Business Review, Vol.78, No. 4, pp. 105-113

[47] Jacoby, J. \& Kaplan, L.B. (2013). The Components of Perceived Risk Paper Presented At the Proceeding of the 3rd Annual

[48] Walker, R.H. and Johnson, L.W. (2006), "Why consumers use and do not use technology-enabled services", Journal of Services Marketing, Vol.20, No.2, pp. 125-135

[49] Pavlou, P.A. (2003), "Consumer acceptance of electronic commerce: integrating trust and risk with the technology acceptance model", International Journal of Electronic Commerce, Vol. 7 No. 3, pp. 101-34

[50] Sekaran, U. \& Bougie, R. (2013). Research Methods for Business: A Skill-Building Approach, 6th Edition (6th ed.). New York City, Wiley.

[51] Krejcie, R. V., \& Morgan, D. W. (1970). Determining sample size for research activities. Educational and Psychological Measurement, 30, 607610.

[52] Malhotra, N. (2014). Marketing Research: An Applied Orientation, 3rd Ed, Prentice- Hall, Sydney.

[53] Teo, T.S.H. and Liu, J. (2002), "Consumer trust in e-commerce: a cross-cultural study", Proceedings of the 62nd Annual Meeting of the Academy of Management, Denver,

\section{Creative Commons Attribution License 4.0 (Attribution 4.0 International, CC BY 4.0)}

This article is published under the terms of the Creative Commons Attribution License 4.0

https://creativecommons.org/licenses/by/4.0/deed.en_US 